Rapp. Grønlands geol. Unders. 99, 107-110 (1980)

\title{
PRELIMINARY Rb-Sr ISOTOPE EVIDENCE ON THE AGE AND METAMORPHIC HISTORY OF THE NORTH GREENLAND CRYSTALLINE BASEMENT
}

\section{F. Kalsbeek and H. F. Jepsen}

No outcrops of crystalline basement rocks are known in the eastern part of North Greenland, mapped in 1978 and 1979 by the Geological Survey of Greenland. The oldest rocks are sandstones of the Proterozoic Independence Fjord Group (Collinson, this report). However, ice-transported boulders of gneisses, amphibolites and granitic rocks indicate the presence of crystalline rocks under the Inland Ice, perhaps not far south of the ice margin (fig. 46). The nearest outcrops of crystalline basement in North Greenland occur at the head of Victoria Fjord, c. $250 \mathrm{~km}$ west of Independence Fjord (Hurst \& Peel, 1979). These rocks have as yet not been mapped or studied.

In Sydpasset, west of Øvre Midsommersø (locality 1, fig. 46), a $60 \times 10 \mathrm{~m}$ large basement fragment was found, enclosed in a dolerite sheet. The inclusion is composed of a leucocratic gneiss and contains a $1 \mathrm{~m}$ thick band of amphibolite which is folded. In the field, the gneiss and amphibolite appeared to be fresh, but in thin section the feldspar proved to be altered. This giant basement inclusion is probably a good representative of the crystalline rocks beneath the Proterozoic platform.

$\mathrm{Rb}-\mathrm{Sr}$ whole-rock isotope measurements have been made of two collections of basement samples:

Fig. 46. Map of the area around inner Independence Fjord with sample localities marked 1 and 2 .

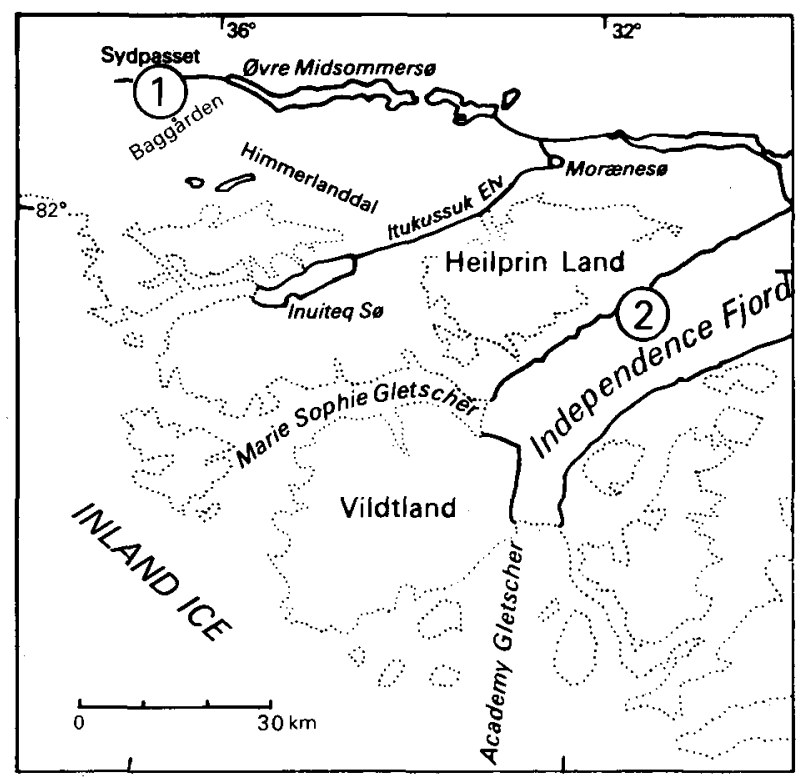


Table 3. $R b-S r$ isotope data and $R b$ and Sr contents for crystalline basement rocks and feldspathic sandstones from eastern North Greenland

\begin{tabular}{|c|c|c|c|c|c|c|}
\hline & & $\mathrm{Rb}(\mathrm{ppm})$ & Sr(ppm) & $\mathrm{Rb} / \mathrm{Sr}$ & ${ }^{87} \mathrm{Sr} /{ }^{86} \mathrm{Sr}$ & ${ }^{87} \mathrm{Rb} /{ }^{86} \mathrm{Sr}$ \\
\hline & $197435^{\S}$ & 124 & 116 & 1.08 & 0.8126 & 3.16 \\
\hline & $197437^{\S}$ & 269 & 67 & 4.03 & 1.1424 & 12.16 \\
\hline & $197439 \mathrm{~A}$ & 243 & 109 & 2.23 & 0.8929 & 5.57 \\
\hline & $197439 B^{\S}$ & 269 & 99 & 2.70 & 0.9251 & 7.98 \\
\hline & 197440 & 281 & 88 & 3.20 & 1.0172 & 9.54 \\
\hline & $197441 \S$ & 133 & 192 & 0.688 & 0.7751 & 2.00 \\
\hline & 197443 & 60 & 238 & 0.252 & 0.7301 & 0.731 \\
\hline & 197444 & 283 & 69 & 4.12 & 1.1400 & 12.43 \\
\hline & 197446 & 63 & 181 & 0.349 & 0.7394 & 1.013 \\
\hline & $197447^{\S}$ & 60 & 364 & 0.166 & 0.7225 & 0.481 \\
\hline & $233802^{\S}$ & 98 & 297 & 0.328 & 0.7353 & 0.953 \\
\hline & $233803^{\S}$ & 53 & 318 & 0.165 & 0.7252 & 0.479 \\
\hline & $233804^{5}$ & 56 & 240 & 0.232 & 0.7296 & 0.674 \\
\hline & $233805^{\S}$ & 80 & 285 & 0.281 & 0.7341 & 0.814 \\
\hline & $233806^{\S}$ & 94 & 244 & 0.385 & 0.7463 & 1.120 \\
\hline & $233807^{\S}$ & 72 & 279 & 0.257 & 0.7325 & 0.747 \\
\hline & $233808^{\S}$ & 70 & 332 & 0.211 & 0.7279 & 0.611 \\
\hline & $233809 \S \dagger$ & 46 & 123 & 0.371 & 0.7372 & 1.078 \\
\hline & $233810^{\S \dagger}$ & 63 & 165 & 0.382 & 0.7442 & 1.110 \\
\hline & $233812^{\S}$ & 111 & 219 & 0.504 & 0.7482 & 1.463 \\
\hline \multirow[t]{5}{*}{ c: } & 273262 & 132 & 42 & 3.17 & 0.9354 & 9.37 \\
\hline & 273264 & 123 & 40 & 3.07 & 0.9335 & 9.08 \\
\hline & 273292 & 202 & 66 & 3.04 & 0.9219 & 8.98 \\
\hline & 273293 & 109 & 33 & 3.26 & 0.9365 & 9.66 \\
\hline & 273402 & 109 & 32 & 3.38 & 0.9575 & 10.02 \\
\hline
\end{tabular}

A: samples from ice-transported boulders collected near Kap Einar Mikkelsen (locality 2, fig. 46).

B: samples from the giant inclusion at Sydpasset (locality 1, fig. 46). ${ }^{\dagger}$ : amphibolite samples.

C: feldspathic sandstones.

For the samples indicated with ${ }^{\S}$ the $\mathrm{Rb}$ and $\mathrm{Sr}$ contents are estimates only $( \pm c .10 \%)$. For the other samples the $\mathrm{Rb}$ and $\mathrm{Sr}$ contents are accurate within c. $2 \%$.

The $\mathrm{Rb} / \mathrm{Sr}$ ratios (by XRF) are relative to USGS G-2 $\mathrm{Rb} / \mathrm{Sr}=0.355$. Precision $\pm 1-2 \%(2 \sigma)$.

The ${ }^{87} \mathrm{Sr} /{ }^{86} \mathrm{Sr}$ ratios are normalised and relative to the Eimer \& Amend $\mathrm{SrCO}_{3}$ standard ${ }^{87} \mathrm{Sr} / 86 \mathrm{Sr}=0.7080$. Precision $\pm 0.0004(2 \sigma)$.

The isochron calculations were made using $\lambda^{87} \mathrm{Rb}=1.42 \times 10^{-11} \mathrm{y}^{-1}$.

(1) Ten samples of ice-transported boulders of gneisses and granitic rocks, collected in 1978 near Kap Einar Mikkelsen on the north coast of inner Independence Fjord (locality 2, fig. 46). These samples have been studied in connection with a $\mathrm{Rb}-\mathrm{Sr}$ isotope study of the Proterozoic intrusive rocks in the area (see Jepsen \& Kalsbeek, 1979). The samples are gneisses of tonalitic and granodioritic composition, amphibolites and leucocratic granitic rocks.

(2) Ten samples from the giant inclusion at Sydpasset, collected in 1979. It was hoped that a study of these samples from one coherent 'outcrop' would give more information on the age and the metamorphic history of the basement than the scattered samples of collection 1. The rocks are quartzo-feldspathic gneisses with varying amounts of $\mathrm{K}$-feldspar and two samples of amphibolite.

The results of the isotopic measurements on these two collections, as well as those on a 
Fig. 47. $\mathrm{Rb}-\mathrm{Sr}$ isochron diagram for crystalline basement samples from eastern North Greenland. The samples were taken from ice-transported boulders found near Kap Einar Mikkelsen at the coast of Independence Fjord (locality 2, fig. 46).

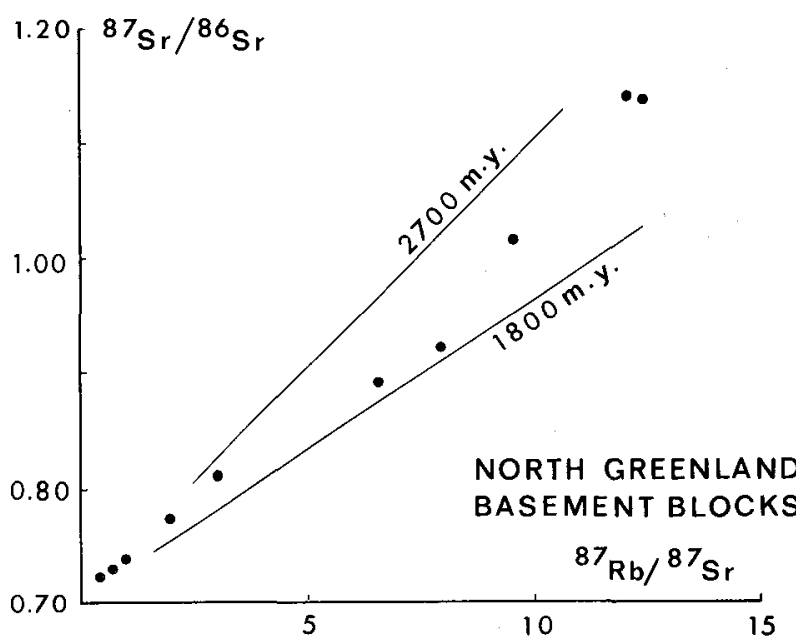

few samples of feldspathic sandstones from the lower part of the Independence Fjord Group in the same area, are given in Table 3 and plotted in figs 47 and 48.

In the ${ }^{87} \mathrm{Sr} /{ }^{86} \mathrm{Sr}$ vs. ${ }^{87} \mathrm{Rb} /{ }^{86} \mathrm{Sr}$ diagrams the measurements do not give isochrons. The erratic boulder samples from Kap Einar Mikkelsen plot in a fan between 2700 and 1800 m.y. reference isochrons (fig. 47). This type of distribution has also been found for rocks from North-West Greenland (Kalsbeek \& Dawes, 1980) and is regarded as characteristic for late Archaean (2800-2600 m.y.) rocks strongly affected by Hudsonian (1800-1600 m.y.) metamorphism.

The data for the samples from the Sydpasset locality and the sandstone samples (fig. 48) support this impression. Eight of the basement samples, as well as the measured sandstones, plot near a $1650 \mathrm{~m}$.y. reference isochron in the ${ }^{87} \mathrm{Sr} /{ }^{86} \mathrm{Sr}$ vs. ${ }^{87} \mathrm{Rb} /{ }^{86} \mathrm{Sr}$ diagram. This can be interpreted as follows:

The feldspathic sandstones of the lower part of the Independence Fjord Group were probably derived from the same metamorphic basement as the erratic boulders and the giant inclusion that we have investigated. The sandstones consist almost exclusively of quartz and $\mathrm{K}$-feldspar, and since quartz contains negligible amounts of $\mathrm{Rb}$ and $\mathrm{Sr}$, the measured isotope ratios must refer to the $\mathrm{K}$-feldspar in the sandstone. This in turn represents the $\mathrm{K}$-feldspar in the basement gneisses, formed during the latest metamorphism of these rocks. Because of the high ${ }^{87} \mathrm{Rb} /{ }^{86} \mathrm{Sr}$ ratios, an estimate of the age of this feldspar is hardly dependent on the choice of the initial ${ }^{87} \mathrm{Sr} /{ }^{86} \mathrm{Sr}$ ratio $\left(\mathrm{Sr}_{\mathrm{i}}\right)$. For $\mathrm{Sr}_{\mathrm{i}}$ values between 0.70 and 0.72 the age estimates vary from $c .1750$ to $c .1600 \mathrm{~m}$.y. This indicates that the latest intense metamorphism of the basement took place between 1750 and 1600 m.y. ago.

This line of reasoning indicates that the $1650 \mathrm{~m} . \mathrm{y}$. line (fig.48), along which most of the samples from the Sydpasset locality plot, dates the metamorphism, and not the original age of the rocks. The high $\mathrm{Sr}_{i}$ value of the 1650 m.y. line (0.713) confirms this and indicates that the original (igneous) age of the rocks must be considerably older. The fact that six of the samples from the Sydpasset inclusion plot near a $2700 \mathrm{~m}$.y. reference isochron suggests that the rocks may be of late Archaean origin. The lowering of the ${ }^{87} \mathrm{Sr} /{ }^{86} \mathrm{Sr}$ ratios for high $\mathrm{Rb} / \mathrm{Sr}$ samples and the increase of ${ }^{87} \mathrm{Sr} /{ }^{86} \mathrm{Sr}$ for low $\mathrm{Rb} / \mathrm{Sr}$ samples would then be the result of 


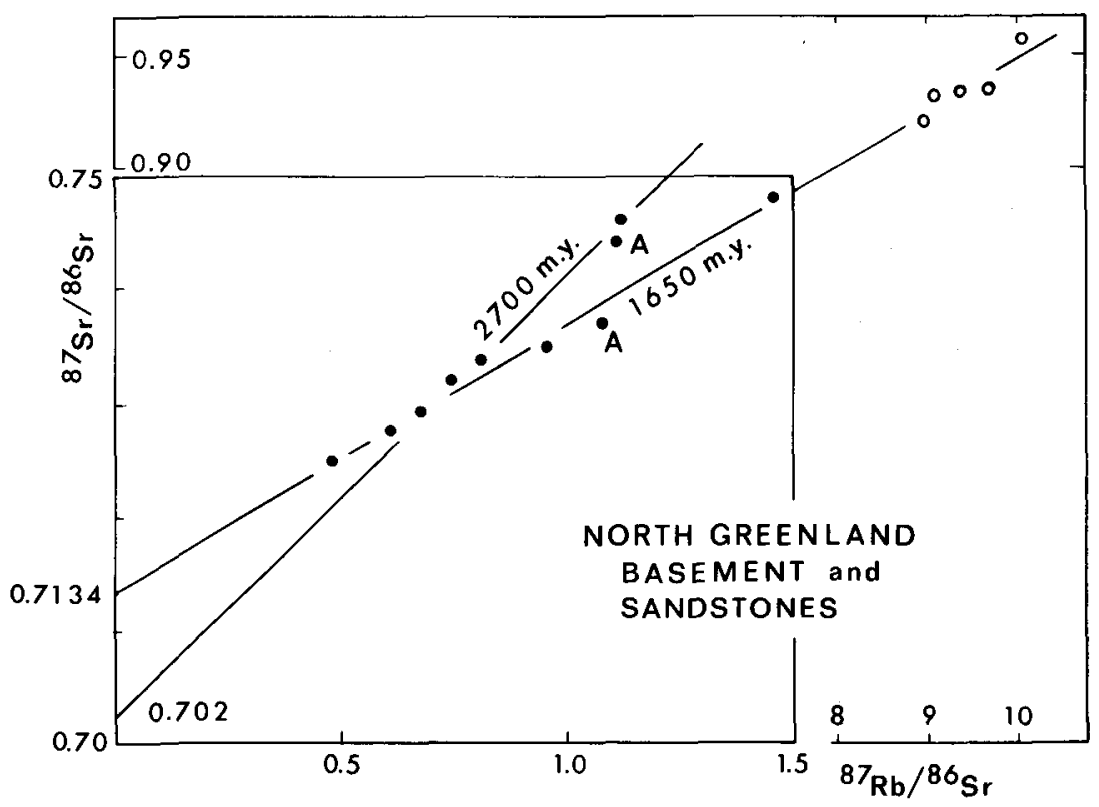

Fig. 48. $\mathrm{Rb}-\mathrm{Sr}$ isochron diagram for crystalline basement samples (dots) and feldspathic sandstones (circles) from eastern North Greenland. The basement samples were taken from a giant gneiss inclusion in dolerite at Sydpasset, west of Øvre Midsommersø (locality 1, fig. 46). The samples marked A are amphibolites.

partial isotopic homogenisation during the Proterozoic metamorphism at 1750-1600 m.y. A comparable case of partial metamorphic resetting of older $\mathrm{Rb}-\mathrm{Sr}$ isotope systems has been described for undoubtedly Archaean rocks, affected by Nagssugtoqidian (1800-1600 m.y.) metamorphism, from near Søndre Strømfjord airbase in West Greenland (Kalsbeek \& Zeck, 1978, fig. 44b).

Acknowledgements. The laboratories for isotope geology and X-ray fluorescence spectrometry of the Institute of Petrology, University of Copenhagen, where the measurements were made, are supported by the Danish Natural Science Research Council (SNF).

\section{References}

Hurst, J. M. \& Peel, J. S. 1979: Late Proterozoic(?) to Silurian stratigraphy of southern Wulff Land, North Greenland. Rapp. Grønlands geol. Unders. 91, 37-56.

Jepsen, H. F. \& Kalsbeek, F. 1979: Igneous rocks in the Proterozoic platform of eastern North Greenland. Rapp. Grønlands geol. Unders. 88, 11-14.

Kalsbeek, F. \& Dawes, P. R. 1980: Rb-Sr whole-rock measurements of the Kap York meta-igneous complex, Thule district, North-West Greenland. Rapp. Grønlands geol. Unders. 100, 30-33.

Kalsbeek, F. \& Zeck, H. P. 1978: Preliminary Rb-Sr whole-rock data for Archaean and Nagssugtoqidian rocks from the Søndre Strømfjord area, West Greenland. Rapp. Grønlands geol. Unders. 90, 129-134. 